\title{
Procedural Regulation of Involuntary Hospitalization ACCORDing TO THE Legal Order of The Czech Republic in COMPARISON WITH GERMAN LEgISLATION ${ }^{1}$
}

\author{
Petr Podrazil, Vojtěch Jirásko
}

Faculty of Law, Palacký University Olomouc, Czech Republic petr.podrazil@upol.cz

PODRAZIL, Petr; JIRÁSKO, Vojtěch. Procedural regulation of involuntary hospitalization according to the legal order of the Czech Republic in comparison with German legislation International and Comparative Law Review, 2019, vol. 19, no. 2, pp. 266-284. DOI: 10.2478/iclr-2019-0024.

\begin{abstract}
Summary: The article focuses on the analysis of the procedural arrangements of detention proceedings in the legal order of the Czech Republic and the Federal Republic of Germany. Special attention is paid to the systematic (conceptual) setting of the functioning of procedural adjustments, whose current form is a reflection of the shift or departure from the historical law ratio legis of civil health detention. The historical ratio legis then consists in the protection of the personal freedom of the mentally ill, who were taken into the institution for the insane against their will. Thus, the links between guardianship and detention should not be neglected in the design of procedural procedures. Both procedures should be closely linked. The aim of the article is to analyze the concept of procedural modifications of detention proceedings under German and Czech legislation, also in connection with partial differences within individual procedural law institutes. Special attention is paid to the mutual relation between detention proceedings and custody proceedings.
\end{abstract}

Keywords: involuntary hospitalization, mental illness, detention proceedings, personal liberty

\section{Introduction}

The right to a person's personal freedom is ascribed to a privileged position among other fundamental rights. Any interference in this right is permitted only by virtue of the statutory exceptions, which must be interpreted restrictively. ${ }^{2}$

1 This article was created as part of the Student Grant Competition project of the Palacký University in Olomouc. Project title: Problematic aspects of civil law involuntary hospitalization in a healthcare facility, project number: IGA_PF_2018_009.

2 The nature of this fundamental right and the system of its protection were discussed in detail in the judgment of the Constitutional Court of the Czech Republic of 23 March 2015, file no. stmp. I. US 1974/14. Further, cf. for example, the judgment of the European Court of Human Rights in the case of Tupa v. Czech Republic of 26 May 2011, complaint no. 39822/07. 
The importance of this right becomes more important when involuntary hospitalization is exposed to persons who are physically handicapped as to the possibilities of consistent protection of their status. The proper protection of rights causes difficulties especially for persons whose legal capacity has been restricted in accordance with substantive law. Thus, the protection of the personal freedom of the vulnerable group must be very consistent, prudent and based on principles allowing respect for the human dignity of the persons concerned.These conclusions also correspond to the case law of the Constitutional Court of the Czech Republic, according to which the fact, that historically persons with intellectual disabilities present a vulnerable group, must also correspond to a particularly cautious interpretation of the legal norms relating to them, which must fully comply with their fundamental rights. Persons with intellectual disabilities carry all human rights and guarantee them protection and respect for their natural human dignity. Therefore, these persons can no longer be excluded from society, their human rights downplayed and treated only as an object of legal regulation and procedures. ${ }^{3}$

The area of legalization of involuntary hospitalizations has its substantive and procedural component (page), each of which is based on a premise that hospitalization of a person without consent constitutes a serious interference with his or her personal freedom, which must be placed under thorough protection by the state. The main task of the substantive sphere of the legal regulation of involuntary hospitalizations is to define the basic legal reasons in which a person can be taken to a closed institution without his / her consent [Article 5(1)(e) of the Convention for the Protection of Human Rights and Fundamental Freedoms]. The fulfillment of these statutory grounds is subsequently examined by an independent and impartial tribunal in proceedings known under its established designation as detention proceedings [Article 5(4) of the Convention].

The article focuses on the analysis of the procedural arrangements of detention proceedings in the legal order of the Czech Republic and the Federal Republic of Germany. Special attention is paid to the systematic (conceptual) setting of the functioning of procedural adjustments, whose current form is a reflection of the shift or departure from the historical law ratio legis of civil health detention. The historical ratio legis then consists in the protection of the personal freedom of the mentally ill, who were taken into the institution for the insane against their will. ${ }^{4}$ Thus, the links between guardianship and detention should not be

3 Judgment of the Constitutional Court of the Czech Republic of 23 March 2015, file no. stmp.I. US 1974/14. On the characteristics of the specific position of disabled people, cf. eg the judgment of the European Court of Human Rights in Stanev $v$ Bulgaria from 17 January 2012, complaint no. 36760/06; and also judgment in the case of Shtukaturov $v$ Russia from 27 March 2008, complaint no. 44009/05.

4 For closer characteristics of international human rights for mentally ill persons see: ZUCKERBERG, Joaquin. International human rights for mentally ill persons: The Ontario experience. International Journal of Law and Psychiatry, vol. 30, issue 6, p. 512-529. See also: HARRIS, David John et al. Law of the European Convention on Human Rights. 2nd 
neglected in the design of procedural procedures. Both procedures should be closely linked. The aim of the article is to analyze the concept of procedural modifications of detention proceedings under German and Czech legislation, also in connection with partial differences within individual procedural law institutes. Special attention is paid to the mutual relation between detention proceedings and custody proceedings.

\section{Characteristics of detention proceedings in the light of case law of the European Court of Human Rights}

The basic presentation of the two mentioned procedural arrangements is reflected in Article 5(4) of the Convention for the Protection of Human Rights and Fundamental Freedoms, under which anyone who has been deprived of his liberty by arrest or otherwise has the right to bring an action whereby the court would without undue delay rule on the legality of his deprivation of liberty and order the release if illegal. The activation of the procedure referred to in Article 5(4) of the Convention should always occur if a person was placed in a closed institute for a minor period without their consent. ${ }^{5}$ The involuntary detainee must be guaranteed the right to initiate a review procedure at "reasonable intervals (time-limits)". The judicial review mechanism may be appropriately reinforced by an automatic periodic review system.

In its rulings, the European Court of Human Rights has set out a number of requirements and specifics for a procedural procedure aimed at establishing the legitimacy of detention. Thus, in accordance with its conclusions, the requirements for this type of procedure are fulfilled by a procedure which is fair and regular, in particular any means of depriving an individual of liberty should be based on the competent authority and should not be arbitery. ${ }^{6}$ In other words, deprivation of liberty cannot be regarded as lawful within the meaning of Article 5 (1) of the Convention, unless national proceedings provide sufficient safeguards against arbitrariness. ${ }^{7}$

According to the European Court, the requirement of the legality of detention undertaken, the proper assessment of which is the main measure of detention, needs to be interpreted as Article 5 (4) has the same meaning as in paragraph

edition. Oxford: Oxford University Press, 2009. 902 p. BARTLETT, Peter, LEWIS, Oliver, THOROLD, Oliver. Mental disability and the European Convention on Human Rights. Leiden/Boston: Martinus Nijhoff Publishers, 2007. 377 p. For social situation of mentally ill persons see: GOFFMAN, Erving. Asylums: Essays on the Social Situation of Mental Patients and Other Inmates. Reprint. Harmondsworth: Penguin Books Ltd, 1973. 386 p.

5 Under the Czech legislation, it must be longer than 24 hours (Section 40 of the Health Services Act).

6 Judgment of the European Court of Human Rights in the case of Winterwerp $v$ Netherlands dated 27 November 1981, application no. 6301/73.

7 Judgment of the European Court of Human Rights in Kędzior v Poland of 16 October 2012, complaint no. $45026 / 07$. 
1 so that the detainee is entitled to review the lawfulness of his detention. not only with regard to the requirements of domestic law, but also with the Convention and the general principles contained therein. Furthermore, the independent review should be sufficiently broad in scope to be able to guarantee compliance with all the substantive conditions of the so-called statutory detention under Article 5(1) of the Convention. ${ }^{8}$

Procedural procedure (proceedings) taking place pursuant to Article 5(4) of the Convention must be of a judicial character and guarantee the involuntarily hospitalized person the guarantees corresponding to the type of deprivation of liberty under consideration. In determining whether the procedure under examination provides adequate safeguards for the person concerned, the specific nature of the circumstances in which the proceedings take place should be taken into account (eg the health status of the involuntarily placed person, aggression of the person, degree of danger to the world). ${ }^{9}$ Viewed from the point of view of the conclusions expressed by the Constitutional Court of the Czech Republic, the assessment of the legality of involuntary hospitalization rests solely with the court, not with another, eg administrative, body. ${ }^{10}$

The specific nature of detention proceedings compared to general judicial proceedings is evident in the analysis of the guarantees under Article 6(1) of the Convention. In the context of detention proceedings, some of the procedural safeguards guaranteeing the right to a fair trial may be delayed in whole or in part. The material (irrevocable, non-cancelable) nature of Art. 6(1) of the Convention, however, must be guaranteed in detention proceedings - detention proceedings must not show signs of arbitrariness in any way. In any case, the involuntarily placed person must be guaranteed the right to be heard, either directly (in person) or indirectly through his or her representative. Likewise, access to a court free from excessive formal obstacles must always be granted to that person. ${ }^{11}$

During detention proceedings (with regard to the specifics accompanying the proceedings), certain essential components guaranteeing the right to a fair trial (eg in the form of abandoning the questioning of an involuntarily hospitalized person) can be or need not be used. However, accession to that procedural restriction can only take place if that procedural measure is proportionate and pursues a legitimate aim. The application of a restrictive procedural measure must be duly substantiated by the court (ie substantively substantiated), eg in the

8 Judgment of the European Court of Human Rights in E. v. Norway, no.11701/85.

9 Cf. judgment of the European Court of Human Rights in E. v. Of 19 August 1990.

10 Cf. Judgment of the Constitutional Court of 30 September 1997, file no. stmp. Pl. ÚS 23/97.

11 See the judgment of the European Court of Human Rights in Kędzior v Poland of 16 October 2012, complaint no. 45026/07, judgment in Stanev v Bulgaria of 17 January 2012, complaint no. 36760/06, DD v Commission Lithuania from 12 February 2012, complaint no. 13469/06, judgment in case of Megyeri vs Germany dated 12 May 1992, application no. 13770/88, judgment in Shtukaturov vs Russia of 27 March 2008, complaint no. 44009/05. 
form of an expert report proving the inability of the person concerned to understand the meaning and substance of the detention procedure. Furthermore, the abandonment of the interrogation of a placed person also entails increased demands on the court in the form of an appropriate burden of argument to justify the need for no interrogation.

\title{
3 Conceptual concept of detention proceedings according to Czech legislation
}

\author{
3.1 Subsequent (acute) control of the legality of detention - detention procee- \\ dings
}

Due to the general binding force of the case-law of the European Court of Human Rights, the above-described characteristics of detention are applicable to all Contracting States which have undertaken to respect the Convention for the Protection of Human Rights and Fundamental Freedoms. The presented basic features of detention proceedings are therefore inherent in both the Czech and German legislation. However, the basic differences between the two procedural modifications are evident in the conceptual setting of procedural protection. Since January 1, 2014, the main core of the procedural regulation of detention proceedings in the Czech Republic is $\$ 66$ and subsequently the Act on Special Judicial Proceedings. This procedural adjustment reflects the requirements arising from Article 5(4)| of the Convention and the case-law of the European Court of Human Rights. Detention proceedings held pursuant to Section 66 and subsequently the Act on Special Judicial Proceedings, has a relatively independent position, at first sight there are no apparent links to other special court proceedings, in particular to guardianship proceedings. According to the German legislation, detention proceedings are, on the contrary, a special type of guardianship procedure, which is enshrined in $\$ 312$ et seq. FamFG. ${ }^{12}$

Czech procedural legislation of detention facilities includes cumulatively 3 types of detention proceedings, namely general (traditional) detention proceedings in the form of so-called proceedings in matters of declaring the admissibility of taking over or holding in a health institution ( $\$ 66$ et seq. The Act on Special Judicial Proceedings), take-over in special cases ( $\$ 83$ of the Act on Special Judicial Proceedings) and historically the youngest proceedings on the declaration of inadmissibility of holding in social service facilities ( $\$ 84$ et seq. the Act on Special Judicial Proceedings). ${ }^{13}$ The process of civilian detention is

12 German Law on Family and Voluntary Judicial Jurisdiction; Das Gesetz über das Verfahren in Familiensachen und in den Angelegenheiten der Freiwilligen Gerichtsbarkeit.

13 With regard to the requirement to provide for judicial protection also in relation to persons involuntarily placed in social services, cf. eg the judgment of the Constitutional Court of the Slovak Republic, according to which no special legal mechanism for the protection of their rights under article 17(1) and (6) and article 23(1) and (3) of the Constitution. That situation cannot be prejudicial to them in the rule of law. Accordingly, the closest similar mecha- 
thus internally differentiated, but on the outside it gives a uniform impression. While the standard detention proceedings held pursuant to $₫ 66$ et seq. the Act on Special Judicial Proceedings is primarily aimed at the protection of persons with mental health problems, the remaining two proceedings are aimed at persons whose reason for taking over was both the acute need to protect the life of an involuntary hospitalized person and persons who are placed in social services facilities without consent.

The fundamental legal regulation of a substantive nature, which contains conditions and legal reasons under which a person can be involuntarily taken to a medical facility, is Act No. 372/2011 Coll., on health services and conditions of their providing ( $\$ 38$ et seq.). Substantive legislation is also supplemented by the provisions of the Civil Code regulating the rights of a person taken to a medical facility without consent ( $\$ 104$ et seq.). From a substantive point of view, there is a special specific combination of public and private legislation, the relationship of which may not always be obvious. ${ }^{14}$

The protective mechanisms of the Czech procedural regulation discussed above are automatically activated when a person is placed in a closed institution without their consent and the involuntary hospitalization exceeds the legal limit of 24 hours ${ }^{15}$ beginning to run from the moment the patient is taken into care.

nism governed by Articles 191 a to 191 f of the GCP must be used to protect those rights. Judgment of the Constitutional Court of the Slovak Republic of 23 August 2000, file no. stmp. III. ÚS 45/00. Further eg the Judgment of the European Court of Human Rights in the case of Kędzior vs Poland, where the European Court found the absence of judicial protection in the case of deprivation of liberty by placing him in a social care facility. According to the Court, in such a case, Polish law did not allow for an automatic judicial review of the legality of detention ex officio; The involuntarily placed person was thus not allowed to use any judicial remedies to challenge the ongoing involuntary institutionalization. That situation led to an infringement of Article 5(4) of the Convention. Judgment of the European Court of Human Rights in Kędzior v Poland of 16 October 2012, complaint no. 45026/07.

14 Doležal speaks at this point that the Civil Code indirectly amends the Health Services Act and extends the catalogue of the rights of the forcibly hospitalized. He also mentions the problematic relationship between the Civil Code and the Health Services Act, for which it is not possible to clearly establish their mutual relationship, which must always be assessed in the case of the application of a specific provision. The mutual relationship of both legal regulations has very unclear contours, eg in the case of an information obligation enshrined in $₫ 105$ para. 1 of the Civil Code and $\$ 38$ para. 6 ZOZS. Cf. Literature DOLEŽAL, Tomáš. In Melzer, Filip, Tegl, Petr. Civil Code. \$1-117. Great comment. Volume I. Prague: Leges, 2013, p. 610.

15 The 24-hour period starts from the moment when the person was taken into the care of the institution without his or her consent, ie from the moment of deprivation or restriction of his / her personal freedom, ie from the moment when the patient "passed" equipment, respectively. from the moment when his / her personal freedom was restricted in the course of hitherto voluntary hospitalization (ie from the moment of the use of means of restraint deployed under $\$ 39$ of the Health Services Act). Cf. judgment of the Constitutional Court of 11 January 2007, file no. stmp. II. US 530/06. Although this is a decision in a criminal case, the conclusions of that decision are applicable to civil detention as regards 
Judicial control of the legality of detention is thus based on posterior protection, when the judicial review takes place only when a person is involuntarily taken into institutional care. This protection is designed for acute cases, where it is not possible to require from a medical facility, or the guardian to fairly obtain prior consent to undergo detention.

Regarding the hospitalization of persons limited in their legal capacity, the legal regulation pursuant to $\$ 76(2)$ of the Act on Special Judicial Proceedings allows the guardian of an involuntarily hospitalized person to give his consent to undergoing detention. The consent given by the guardian means that detention proceedings need not be initiated, since detention is automatically regarded as lawful. In case the consent to hospitalization was expressed by the guardian, the placed person has the right to file a petition to initiate proceedings pursuant to $\$$ 76(2) of the Act on Special Judicial Proceedings. However, the chosen concept of the protection of the mentally ill does not seem to be very appropriate, since the commencement of legal proceedings is connected with the procedural activity of an involuntary detainee, which can be very difficult, if not impossible, in the specific case. Judicial protection should be automatic, the guardian should not be granted the right to consent to a stay in the institution instead of the person concerned. This situation contradicts the requirements of the case-law of the European Court of Human Rights and unduly lowers the level of protection in the case of involuntary hospitalization of persons with limited legal capacity. The level of protection set in $\$ 76(2)$ of the Act on Special Judicial Proceedings is very problematic as it does not take into account the concept of consent to hospitalization expressed by the European Court of Human Rights in Shtukaturov v.Russia, where the European Court has defined the need to differentiate between the ability to give consent to de jure and de facto hospitalization. With regard to the need to guarantee increased protection of persons restricted in their legal capacity during their involuntary hospitalization, it is necessary that the consent to hospitalization is not formally viewed as the consent or disagreement must be inferred from any factual behaviour of the placed person. If, for example, an involuntarily placed person resorts to attempts to escape from the institution, where they were placed without consent, or if they urge the head of the institute to ask for dismissal, it is obvious that they did not express their consent to their hospitalization; it is necessary to deduce disagreement with the placement from their conduct. ${ }^{16}$ In such a case, it is necessary to initiate proceedings in which

the moment of restriction or deprivation of liberty.

According to the reason of hospitalization it may happen that during this $24 \mathrm{~h}$ period the initial hospitalization without consent changes to the voluntary hospitalization (with the consent). See HUSTOFT, Kjetil; LARSEN, Tor Ketil; BRØNNICK, Kolbjørn; JOA, Inge; JOHANNESSEN, Jan Olav; RUUD, Torleif. Voluntary or involuntary acute psychiatric hospitalization in Norway: A $24 \mathrm{~h}$ follow up study. International Journal of Law and Psychiatry, vol. 56, January-February 2018, p. 27-34.

16 Judgment of the European Court of Human Rights in Shtukaturov v Russia of 27 March 2008, complaint no. 44009/05. 
the legality of the detention undertaken is ascertained. Activation of court proceedings cannot be prevented by consent given by the guardian of the placed person, as the standard of protection of personal freedom would be rapidly lowered by this procedure. Subjective side of Article 5(1) of the Convention cannot therefore be assessed solely on the basis of the legal status of the placed person; the person's ability to de facto understand his / her own situation must be taken into account. The decisive factor is thus not the legally formal ( rechtsgeschäftlicher ) but the natural ( natürliche ) will of the placed person. ${ }^{17}$ No other person (such as his / her guardian) can demonstrate the will for this person.

\subsection{Preliminary (non-acute) control of the legality of detention - guardianship}

Apart from subsequent (acute) judicial control, Czech law recognizes another branch of protection against illicit detention, which is targeted at other cases, ie cases where sufficient time is given to control planned detention while the involuntary placement in a closed institution is at the preparation phase. The protection mechanism is built on a priori and non-acute principle. The control within this second branch does not always have to be entrusted to a lawful and impartial court - in one case, the guardian council (see below) may assume the role of a supervisory (protective) mentor instead of the court. Control mechanisms within the system of such protection aim to protect the personal freedom of an involuntarily placed ward in a closed institution, as well as to protect his/ her property, while it is clear that in assessing the significance of both competing interests, the interest in the consistent protection of personal freedom must prevail.

The second branch (guardian-type) of the control mechanisms is ancillary to the follow-up (detention-type) judicial review, which can be applied if the placement of a person with limited legal capacity is not carried out due to an acute threat to the internee's health. ${ }^{18}$ The range of these cases will be very narrow, since involuntary hospitalization of a person of limited legal capacity will be carried out in most cases for medical reasons. However, it is conceivable that such cases will include, for example, institutional stays caused by the inability to take care of oneself or to arrange for everyday needs.

17 BIENWALD, Christa. In BIENWALD, Werner, SONNENFELD, Susanne, BIENWALD, Christa, HARM, Uwe. Betreuungsrecht. Kommentar. 6th edition. Nördlingen: CH Beck, 2016, p. 491. For the hospitalization of the mentally ill persons also the requirements expressed in the so-called Winterwerp test must be fulfilled according to the European Court. See also the judgment of the European Court of Human Rights in Winterwerp $v$ Netherlands dated 27 November 1981, application no. 6301/73.

18 Specifically, the legal reasons justifying acute hospitalization are defined in $\$ 38(1)$ (b)(c) of the Health Services Act. 
3.2.1 The guardianship proceedings due to the placement of a ward into a closed institution

In this case the protection of the placed person is based on the provision of $\$ 480(1)$ (b) of the CC, according to which the guardian of a person under limited jurisdiction may not, without the consent of the guardian council, decide to place the ward in a closed institution or similar facility unless the medical condition of the ward clearly requires it. ${ }^{19}$ At the same time, if the custodial council is not established, the custody of the parties to the ward is approved by the court instead of the custody council [ $\$ 482(2)$ of the CC].

The Ombudsman, in cases where a person with limited legal capacity is placed in a closed institution, has defined the basic limits (which mainly burden the guardian of the person) to be respected before placing the person into the institution.In accordance with his / her conclusions, the following applies: A person with a disability (the ward) has the right to live in a natural environment. The guardian must endeavor to ensure that the person under custody has the opportunity to live an independent way of life and to be integrated into society. To do this, they should use all the available services provided in the home environment or field services. The choice to use the services of a residential facility, which by its very nature constitutes a certain restriction on the freedom of a person and his / her independent way of life, should only be made when it is clear that the person under custody is unable to live with the help and support provided in a less restrictive environment. The guardian should ensure that the ward is integrated into society and should take advantage of the appropriate support measures. The activities of a guardian should not be only formal - a guardian should actively contribute to the protection of the rights of a person placed in a closed institution: A guardian should be active in their role according to the law on social services (in the individual planning), regularly meet the ward, and consistently monitor the quality of the care provided. ${ }^{20}$ Furthermore, according to the Ombudsman, the preference of the natural social environment over the residential social service is generally to be respected, but not absolutely. In all cases, it is necessary to take into account the complex, consistently mapped interests of a person, among which health indications and the protection of the life and health of the person assessed play a primary role. ${ }^{21}$

19 On the mutual status of the guardian and the guardian council cf. judgment of the District Court of Svitavy, according to which the responsibility for the proper conduct of guardianship lies primarily with the guardian, not the guardian council. Judgment of the Svitavy District Court of 12 January 2017, file no. stmp. OP 284/2014.

20 Opinion of the Ombudsman on the exercise of public guardianship in the provision of social services with special regard to the risks of the so-called unregistered social services of 23 September 2015, sp. zn.541/2014 / VOP / RJA.

21 Ombudsman's Opinion on Public Guardianship - Investigation Report of 12 July 2016, sp. zn. 1955/2016 / VOP / JS. 


\subsubsection{Guardianship proceedings for continuous or repeated performance}

The initiation of guardianship proceedings will not occur only in case of nonacute placement of the ward in a closed institution according to $\$ 480$ (1)(b) of the Civil Code in relation to $\$ 482(2)$ of the CC. Guardianship proceedings must also be conducted in a situation where the guardian is to conclude a contract on behalf of the ward obliging him / her to a continuous or repeated performance for more than three years [ $\$ 483(2)(d)$ of the Civil Code]. ${ }^{22}$ Since the placement of a ward in a closed institution will usually be connected with the necessity of concluding a contract obliging them to repeat the service for a longer period of time, it can be expected that guardianship proceedings will have to be opened also in this case.

\section{Partial conclusions in relation to the Czech concept of procedural regu- lation of detention proceedings}

Although the legislation in both described types of guardianship is aimed at protecting different values (personal freedom, integrity, human dignity vs. ward's property), both types of guardianship represent some form of control that prevents the involuntary placement of the ward in a closed institution. These guardianship proceedings are further supplemented through detention proceedings, which constitute the main control mechanism in the form of acute (follow-up) judicial control of involuntary hospitalization.

Although it may be argued that the existence of the widest possible range of control mechanisms in relation to detention without consent must be assessed solely positively, the current concept of the procedural regulation of involuntary hospitalization of mentally ill persons does not give a consistent impression. Certain shortcomings of the overlapping procedural regulations can be seen in the mutually unclear relationship between guardianship and detention. While detention proceedings are primarily aimed at all situations in which a person is admitted to a closed institution for health reasons without consent, guardianship is directed to protect the ward from being placed in a closed institution or similar facility if the medical condition clearly does not require it, then the protection of the ward's property is repeatedly and in the long term burdened by payments to this facility. The boundaries between the first and second branches of procedural protection (detention vs. guardianship branch) are very closely connected, sometimes almost indistinct. It can be noted that the objectives of guardianship proceedings, in which the placement of a ward in a closed institution is checked,

22 In both cases, guardianship protection will primarily apply to long-term institutional stays. The situation is different, for example, in day care centers. In this respect, the District Court in Vsetín concluded that the conclusion of a contract for providing social services of a day care center for a fixed period of one year does not fall under any of the cases and the conclusion of the contract is thus fully in the competence of the guardian. Judgment of the District Court in Vsetín of 30 October 2016, ref. 0 P 21/2010-167. 
and those of detention proceedings, which assess the existence of a substantive reason for hospitalization of a person without consent, largely overlap. In both cases, it is examined whether placement without consent is in the interests of the person, whether placement is a manifestation of arbitrariness, and whether the placement saves and respects a person's personality, his/her moral and physical integrity, including his/her dignity. In practice, there may be a situation where a person placed in a closed institution on the basis of the procedure under $\$ 480$ (1) (b) in relation to $\$ 482$ (2) of the Civil Code (detention carried out in the regime of preliminary protection) subsequently refuses to stay, or some of the means of restraint will be used without the consent of the person concerned (eg administration of psychopharmaceuticals, bedding, etc.)In such a case, it is probably appropriate to initiate detention proceedings as a follow-up pursuant to Section 66 et seq. of the Code on Special Court Proceedings (292/2013 Coll.) - SCP.

The substantive reason in this case is based on $₫ 38$ (1) ( b) and (c) of the Health Services Act.

Regarding the nature of both these proceedings, it should be noted that the guardianship court is in a long - term contact with the ward, which had already been started at the moment of appointment of a guardian to this person ( $\$ 465$ (1) of the Civil Code). The guardianship court keeps a long-term court file on the assessed person, knows the person's needs and, with regard to the legal requirement of continuous supervision of the court over the fulfillment of the guardian's duties, is in regular contact with the ward. The conception of local jurisdiction in guardianship proceedings is based on the concept that the guardianship proceedings are governed by the locally competent court in whose district the ward resides. At the same time, in the event of a change in circumstances, the legislation provides for the transfer of the local jurisdiction of the guardianship court (Section 5 of the SCP). ${ }^{23}$ Guardianship proceedings are summary proceedings (ongoing) and take place in all cases that are relevant to the life of the assessed person (ie the ward).

Detention proceedings, on the other hand, take place at random and solely for the purpose of assessing the legality of the involuntary admission to a medical facility, respectively for the purpose of assessing the admissibility of restrictions on the person 's personal freedom during involuntary hospitalization. The court gets into first contact with the hospitalized person during the detention proceedings, it does not know this person, it is not aware of the development of his / her health condition or any other circumstances of the hospitalized person's life.Local jurisdiction in the context of detention proceedings is based on the

23 The delegation of local jurisdiction laid down in section 5 of the SCP is an exception to the perpetuatio fori principle, according to which the circumstances prevailing at the time of the opening of the proceedings are decisive for determining the substantive and local jurisdiction until the end of the proceedings.(cf. $\$ 11$ Civil Procedure Code). 
view that the detention proceedings are governed by a court in whose district the health institution is located.Thus, this court does not always have to be a guardianship court. If the court of detention is different from the court of guardianship, it is possible to recommend that the court of detention requests the file from the court of guardianship. At the same time, the legislation does not allow the transfer of jurisdiction, which may cause difficulties especially in situations of transfer of a patient to another facility outside the district of the detention court. ${ }^{24}$

Increased interaction of detention proceedings is evident especially in connection with proceedings in matters of human guardianship, namely in cases of involuntary hospitalization of mentally ill persons. The close interconnection of both legal proceedings has its substantive reason, based on the original purpose (reason) of detention proceedings, which was considered from the very beginning as a procedural instrument laid down by law to review the legality of hospitalization of mentally ill persons who were taken into the paychiatric institution against their will. ${ }^{25}$ At the same time, these mentally ill persons who are taken into institutional care without their consent must also be protected by appointing a guardian to take care of their interests and needs with the greatest care and caution. ${ }^{26}$

\section{The concept of detention proceedings under German legislation}

The German legislation considers the issue of guardianship and detention proceedings differently from the concept of the above-mentioned Czech law, which treats both proceedings as two separately regulated judicial procedures, with no closer procedural links between them. On the one hand, guardianship proceedings systematically and at the same time materially precede detention proceedings. As far as the scheme is concerned, the guardianship procedure is based on the provisions of Sections 271-311 of the Act on Family and Family Matters (FamFG). ${ }^{27}$ Placement proceedings ( Unterbringungsverfahren ) known in the Czech law as proceedings on the declaration of admissibility of taking and further holding in a health institution, or civil-detention proceedings, follow up $₫ 312-339$ of the FamFG on the regulation of guardianship proceedings. Although it is not part of the guardianship proceedings, the mutual proximity

24 Change of local jurisdiction in the present case is possible on the basis of the delegation for reasons of suitability ( $\$ 12(2) \mathrm{CPC})$.

25 This historical purpose of detention is currently complemented by efforts to prevent the stigmatization of the involuntary placement in a closed institution - especially in a facility providing psychiatric care.

26 For the purpose and importance of guardianship, cf. eg Supreme Court judgment of 26 May 2011, file no. stmp.21 Cdo 3871/2010. From the case law reflecting the new legal regulation of human guardianship cf. eg the Supreme Court judgment of 16 January 2019, file no. stmp.30 Cdo 2211/2018.

27 Gesetz über das Verfahren in Familiensachen und in der Angelegenheiten der Freiwilligen Gerichtsbarkeit (FamFG). 
of the two partial regulations is evident from the conception of the sequence of these proceedings, the guardianship proceedings are the primary proceedings and placement proceedings are secondary proceedings, as a further optional solution.

Furthermore, the German concept of legislation is based on the assumption that, in principle, questions of involuntary hospitalization and the use of means of restraint can only be decided after a (substantive) guardian has been appointed for an involuntarily placed person. In most aspects, placement proceedings are a mirror of guardianship proceedings (for example in terms of local jurisdiction or procedural process), which in many cases may constitute an advantage for the court to be aware of the file and partial uniformity of the procedure (eg the duty to question the assessed persons).

Placement proceedings apply to the permission or order of several independent institutions (life situations), which are substantively regulated in separate standards, but procedurally the same procedure is applied to these instruments. The first is the question of involuntary hospitalization based on the German Civil Code ('the BGB'). ${ }^{28}$ The aforementioned procedural regulations are also applicable to the use of means of restraint (mechanical means, medicines or other deprivation means - mechanische Vorrichtungen, Medikamente oder auf andere Weise), ${ }^{29}$ also for the procedure appropriate for medical restrictive measures (ärztlichen Zwangsmaßnahmen). ${ }^{30}$ The last of the placement matters is the involuntary placement depriving of personal freedom resulting from provincial laws. ${ }^{31}$ The procedure is thus uniform for all the above-mentioned substantive areas, which are characterized by a common unifying element consisting in invasive interference with the personal human freedom.

It is thus possible to substantively differentiate between the civil placement approval and the public placement order according to the specific private or public branch of the regulation. Private branch is based on Amendments to the German Civil Code $-\$ 1906$ (1), 2 BGB (questions of involuntary hospitalization), $₫$ 1906 (4) BGB (questions on the use of restraints) and $\$ 1906$ a BGB (questions on medical restraints). Hereinafter referred to as " measures" (Maßnahmen) in the sense of all these substantive institutes. The public law branch (in terms of involuntary hospitalization) is then based on the provincial laws of the sixteen Länder . These closely resemble the Czech public law in the Act on Health Services, because (eg according to the Bavarian $\mathrm{Act}^{32}$ ) involuntary hospitalization is only

28 Under section 1906 (1) and (2) of the Bürgerlichen Gesetzbuches.

29 The substantive basis of the application of restraint is $₫ 1906$ (4) BGB.

30 A medical restrictive measure is an involuntary examination, treatment or intervention in accordance with Section 1906a of the BGB.

31 These are the sixteen provincial laws that are called similarly "The Laws on the Support, Assistance and Care of the Mentally Ill".

32 Bayerisches Psychisch - Kranken - Hilfe - Gesetz (BayPsychKHG) Vom 24.July 2018 (GVBl. 583) BayRS 2128-2-A / G, available online at: https://www.gesetze-bayern.de/Content/ 
possible in the case of self-harm to the patient, provided that the restriction does not last longer than six months and there is no other sufficient care or preventive assistance.For meeting the legal requirements ${ }^{33}$, the district administration may order the immediate (involuntary) hospitalization within a health facility or psychiatric hospital if a court decision cannot be taken in time.In such a case, the medical facility is under obligation to notify the court of the restriction of personal freedom within twelve hours. The court must decide by the next day, otherwise the patient must be released. ${ }^{34}$

As mentioned above, guardianship proceedings are primary proceedings in relation to the proceedings in the matter of authorisation, which may or may not be built on them. If, following the appointment of a guardian, there is a need to impose restrictive measures, the appointed guardian gives the consent .The legality of the consent is then (secondarily) assessed in the placement proceedings. ${ }^{35}$ The subject of the proceedings itself is (pre-determined) assessment of the guardian's consent to involuntary hospitalization, application of a means of restraint or medical restraint. ${ }^{36}$

The parties to the German detention proceedings are primarily the person concerned, ${ }^{37}$ guardian and an authorised person. Furthermore, a court-appoint-

Document/BayPsychKHG?AspxAutoDetectCookieSupport=1 .

33 Influenced by mental disorder, threat to health, interests of others or general interest.

34 Cf. $\$ 5$ par. $1, \S 11$ par. $1, \S 14$ BayPsychKHG.

35 This procedure applies with the exception of a special interim measure .A special precautionary measure comes into play when there is an urgent need for a temporary regulation of the circumstances of the person concerned (eg in the case of immediate health threat). A decision on involuntary hospitalization or the application of restraint is issued without hearing the person concerned and his/her guardian. In general, however, there is both an interim measure (without an attribute) and a special interim measure (see above). The application of the interim measure (without the attribute) is only possible if (1) the person concerned and his/her guardian have been heard; the use of means of restraint and there are urgent reasons for further action. The aim of the proceedings is to issue a special interim measure, thus largely resembles the domestic legislation enshrined in Section 83 of the DSU. Further, cf. LUD. $\$ 312$ In Keidl, Theodor et al. FamFG Gesetz über das Verfahren in Familiensachen und in den Angelegenheiten der Freiwilligen Gerichtsbarkeit. Kommentar. 19 Dec Auflage. München: CH Beck, 2017, p. 2235.

36 BUDDE, LUTT. $\$ 312$ In Keidl, Theodor et al. FamFG Gesetz über das Verfahren in Familiensachen und in den Angelegenheiten der Freiwilligen Gerichtsbarkeit. Kommentar. 19 Dec Auflage. München: CH Beck, 2017, p. 2235.

37 The person concerned, or 'Der Betroffene`, is a term for a person whose restriction of freedom is pursued. Czech processualism uses the term "placed person" here ( $\$ 69$ of the SCP). This legislative abbreviation has undergone some development in the Czech law .Initially, a person taken to a healthcare facility was referred to as "sick" without his or her consent. An amendment to the Code of Civil Procedure implemented by Act No. 205/2005 Sb., with effect from 1 August 2005, replaced the term "sick" with the term "placed". According to the explanatory report, the cause of this changes the fact that the term "patient" referred only to a person without consent placed in a medical institution rather than from people who seem to have been taken with their consent, however, during treatment there was a 
ed procedural guardian or the competent authority may intervene in the proceedings at his / her request. ${ }^{38}$ At the same time, the parties may be persons representing the interest of the person concerned..$^{39}$ The range of parties to proceedings under the Czech concept of detention proceedings is defined in Section 67 of the SCP, according to which, in addition to a placed person, a health institution and legal guardian of the placed person filing an application to initiate proceedings on his/her behalf, may be the parties to proceedings.

As regards to procedural capacity, according to the German concept, the person concerned is guaranteed full procedural capacity, which, according to section 316 of the FamFG, does not depend on the degree of legal capacity of the person concerned in the sphere of substantive law.In comparison with the Czech procedural rules, a higher standard of legal protection for the persons concerned is obvious, especially, in the provisions of $\$ 20$ (1) of the Civil Procedure Code - CPC, under which anyone can legally act before the court as an independent party (procedural capacity) to the extent of his/her capacity.

A procedural guardian, who may be a party to the proceedings, must be appointed if it is necessary to safeguard the interests of the person concerned.The appointment of a procedural guardian is particularly necessary if, in the course of the proceedings, the person concerned is refrained from questioning or it is obligatory necessary if medical restrictive measures are to be applied during hospitalization .If no procedural guardian is appointed, the court must deal with this procedure by reasoning in the final decision.Compared to the Czech legislation, a placed person must always be obligatorily represented by an authorised person of his/her choice, if the placed person fails to choose an authorised person or if it

restriction on their freedom or the contact with the outside world. Although the terminology could not be welcomed, the new designation chosen for a person taken to a closed institution without consent (in the form of a legislative abbreviation 'placed') was not as well suited as the term 'placed' could evoke a connection with criminal character. In an attempt to introduce more humane terminology, the Act on Special Procedures for Human Beings uses the involuntary hospitalized designation 'placed person'. Unfortunately, the chosen terminology does not correspond to the terminology used in the Civil Code which only operates with the term "man" ( $\$ 104$ et seq.OZ), or with the terminology contained in the Act on Health Services, which uses the term "patient" ( $\$ 38 \mathrm{ZOZS}$ ). In order to harmonize the terminology used in all three mentioned codes, it is recommended that the legislator proceed with the introduction of a unified concept - for example, a hospitalized person, resp. inpatient.

38 Administrative authorities are specified in the framework of individual provincial laws.In Bavaria, for example, it is the district administration (Kreisverwaltungsbehörde), and in the Saarland three administrative authorities at the district, county and provincial capital level (die Landkreise, der Regionalverband Saarbrücken und die Landeshauptstadt Saarbrücken).

39 These are (1) spouses or partners (if they are not permanently separated), parents and children (if they lived with them at the time of the commencement of proceedings), foster parents; 2) credible persons; (3) the manager of the establishment where the person concerned lives. Other persons and authorities may determine individual provincial laws. 
is necessary to protect the interests of the placed person, a procedural guardian will be appointed from among lawyers. (Section 69 of the SCP).

The local jurisdiction of the court to conduct proceedings is based on the following aspects, which are uniform for both general guardianship and for placement. Primarily, the jurisdiction has the court where guardianship proceedings were initiated.Secondarily, the jurisdiction has the court in whose district the person concerned resides. If this court cannot be determined, the jurisdiction has the court in whose district the need for placement in the institute arises and if this court cannot be so clearly determined, the Municipal Court of Schöneberg in Berlin will have jurisdiction. ${ }^{40}$ In particular, the jurisdiction of the court is regulated when the person concerned is already in a deprivation of liberty facility, typically a medical facility. At that time, the court in whose district the facility is located has an exclusive jurisdiction.If there is a fragmentation of jurisdiction in the case of guardianship and detention proceedings, the courts have a standardized mutual notification obligation. The court of guardianship must inform the court deciding on involuntary hospitalization of the abolition of the guardianship, a change of the defined range of duties or the change of the guardian, while the court of detention informs the guardian court of measures consisting in involuntary hospitalization, alteration, extension or cancellation. Delegation of local jurisdiction is another instrument designed to ensure the speed and effectiveness of a procedure whereby a court can refer detention proceedings to the court in whose district the person concerned resides, provided that the court is willing to take the proceedings voluntarily.

Questioning of the person concerned constitutes a substantial part of the trial itself, since the court is, in principle, obliged to conduct that interrogation with respect to its own need and personal appreciation. If necessary, the court visits the person concerned in his/her usual environment, but it is also possible to bring the person before the court to provide court cooperation. This procedure is performed within the public branch, through the competent authorities and the police. These authorities may, with the consent of the court, proceed through the use of coercive measures or a court-authorized intrusion into the dwelling of the person concerned. The questioning may exceptionally be waived if there is a risk of serious injury to the person concerned. To proceed with the absence of interrogation is possible only on the basis of an expert opinion. Interrogation of the person concerned should not only serve to verify the alleged facts, but also serves as a tool for informing the person concerned about the possible course of proceedings (if the person concerned is able to perceive and understand this information in view of his health).

40 This universal and residual jurisdiction is given only when a citizen of the Federal Republic of Germany is concerned. The interlocutory court has jurisdiction where the need for interim adjustment arises. At the same time, it is necessary to inform the court that has jurisdiction according to the above rules. 
An expert opinion on the necessity of a measure (in the form of involuntary hospitalization, the use of a means of restraint or the application of a medical restrictive measure) is an essential part of the evidence process, where an expert (an experienced psychiatrist) examines or at least interviews the person concerned.The content of the expert opinion should also focus on the expected duration of the restrictive measure. In the case of a medical restrictive measure, the treating physician of the person concerned must not be an expert.

The merit decision contains both a more detailed definition (specification) of the given measure and a deadline by which the measure is to be terminated. In relation to medical restrictive measures, the decision also contains information on the implementation and documentation of the measure.The physician is subsequently responsible for the proper execution according to the decision.

The decision ordering the measure becomes final and enforceable.At the same time, it is possible to decide on the provisional enforceability of the resolution. The decision imposing restrictive measures must be communicated to the person concerned. Communication of the decision to the person concerned may be waived if, in the opinion of the medical opinion, this is necessary in order to prevent serious injury to the patient. The order must also be delivered to the manager of the facility in which the person concerned is to be placed. The enforceability of a decision ordering the use of a means of restraint may be postponed for up to six months (renewable for up to one year). Delays in enforceability may also be linked to the fulfillment of a certain condition (eg deterioration of health condition, disrespect of the treatment regimen, patient decompensation, loss of orientation in time, space and location).

The deadline for issuing a decision is absent from the Czech legislation, probably with regard to the preliminary character of the proceedings. As mentioned above, the deployment of measures which have been consented to by a guardian or an authorised person, is decided pro futuro. The legality (legitimacy, necessity) of this consent is then assessed by the court. In this case, human freedom can be admittedly restricted only after the court has approved the restrictive intervention. The court decision itself prima facie is delivered before the application of the measure. On the contrary, the subsequent character of the proceedings represents the court decision on the admission of the person concerned on the basis of a specific provincial law. Within the branch of public law, there is a restriction of personal freedom first and then a judicial review, on the private level it is the opposite. The Czech and German legal regulations differ considerably, since the Czech legal regulation is based only on the subsequent control and subsequent decision within the framework of the public law regulation of the Health Services Act.Preliminary assessment and decision on involuntary hospitalization is not anticipated by the Czech private law regulation. 


\section{Conclusion}

Identical features between Czech and German legal regulations were revealed by the submitted analysis of the conceptual conception of proceedings which aimed to provide due protection of a person's personal freedom who was placed in a closed institute without his/her consent. These points relate in particular to the area of interrogating (interviewing) the placed person, which is given increased importance in both legal regulations, with an emphasis on the duty of the direct contact of a judge with the placed person. Some divergences are evident in the concept of the parties, where the German concept is built on the broadest possible basis with regard to the consistent defense of the interests of the placed person. The concept of the ability to act independently in proceedings before the court according to German legal regulation, which is not dependent on the substantive sphere (ie it is independent of the degree of legal capacity of the person concerned), can also be viewed positively.

The most fundamental variance can be found in the concept of detention proceedings, where Czech procedural law considers detention proceedings as independent proceedings without defining closer links with guardianship proceedings. On the contrary, the German legislation closely links the placement procedure with the guardianship procedure and is based on the assumption that the involuntary placement of a person in a closed facility is primarily possible with the prior consent of the guardianship court. Other cases are considered as divergences from the general legal regulation of involuntary placement of persons restricted in their legal capacity.Thus, primarily the same court should have jurisdiction to conduct guardianship proceedings and proceedings to assess the legality of the considered restrictive measure. If, in certain circumstances, jurisdiction is split (since it is not possible to ensure an assessment by the court before the measure is taken), the German legislation imposes a duty of close cooperation between both competent courts (ie the court of guardianship and the court assessing the legality of the detention).

In contrast to the German legislation, the Czech legal system recognizes several control mechanisms serving to protect the personal freedom of a person placed involuntarily. It is a branch in the framework of detention proceedings, then the protection provided in the framework of guardianship proceedings. Both types of proceedings are not closely related. The fundamental failure of Czech procedural regulation can be found in the absence of closer ties and the duty of consistent cooperation between the guardianship courts and the detention courts. There are thus considerations on the unification of the local jurisdiction of the court, respectively establishing an obligation for the proper cooperation between the above-mentioned courts. 
ICLR, 2019, Vol. 19, No. 2.

\section{References}

BARTLETT, Peter, LEWIS, Oliver, THOROLD, Oliver. Mental disability and the European Convention on Human Rights. Leiden/Boston: Martinus Nijhoff Publishers, 2007. 377 p. BIENWALD, Christa. In BIENWALD, Werner, SONNENFELD, Susanne, BIENWALD, Christa, HARM, Uwe. Betreuungsrecht. Kommentar. $6^{\text {th }}$ edition. Nördlingen: $\mathrm{CH}$ Beck, 2016, p. 491.

DOLEŽAL, Tomáš. In Melzer, Filip, Tegl, Petr. Civil Code. \$1-117. Great comment. Volume I. Prague: Leges, 2013, p. 610.

GOFFMAN, Erving. Asylums: Essays on the Social Situation of Mental Patients and Other Inmates. Reprint. Harmondsworth: Penguin Books Ltd, 1973. 386 p.

HARRIS, David John et al. Law of the European Convention on Human Rights. $2^{\text {nd }}$ edition. Oxford: Oxford University Press, 2009. 902 p.

HUSTOFT, Kjetil; LARSEN, Tor Ketil; BRØNNICK, Kolbjørn; JOA, Inge; JOHANNESSEN, Jan Olav; RUUD, Torleif. Voluntary or involuntary acute psychiatric hospitalization in Norway: A $24 \mathrm{~h}$ follow up study. International Journal of Law and Psychiatry, vol. 56, January-February 2018, p. 27-34.

ZUCKERBERG, Joaquin. International human rights for mentally ill persons: The Ontario experience. International Journal of Law and Psychiatry, vol. 30, issue 6, p. 512-529. 